Phosphorus Research Bulletin Vol. 22 (2008) pp. 1-6

\title{
INFLUENCE OF TEMPERATURE $\left(20^{\circ}-1000^{\circ} \mathrm{C}\right)$ ON THE PHASE CHANGES IN $\mathrm{Li}_{2} \mathrm{CO}_{3}-\mathrm{MgHPO}_{4} \cdot 3 \mathrm{H}_{2} \mathrm{O}$ SYSTEM
}

\author{
Michal Henryk Umbreit ${ }^{*}$, Agnieszka Jedrasiewicz ${ }^{1}$, \\ Dominik Paukszta ${ }^{2}$, Natalia Szyda ${ }^{1}$. \\ (*Corresponding author: umbreitm@main.amu.edu.pl)
}

\author{
${ }^{1}$ Department of Inorganic and Analytical Chemistry , Faculty of Pharmacy, Poznan University of Medical \\ Sciences, Grunwaldzka 6, 60-780 Poznan, Poland \\ ${ }^{2}$ Poznan University of Technology, Faculty of Chem. Technology, ul. Piotrowo 3, 60-965 Poznan, Poland
}

Keywords: $\mathrm{Li}_{2} \mathrm{CO}_{3}, \mathrm{MgHPO}_{4} \cdot 3 \mathrm{H}_{2} \mathrm{O}$, binary mixtures, TG, DTG. DTA, IR, WAXS.

\begin{abstract}
We analyzed thermal phase changes of substrates $\left(20^{\circ}-1000^{\circ} \mathrm{C}\right)$ of binary mixtures $\mathrm{Li}_{2} \mathrm{CO}_{3}-\mathrm{MgHPO}_{4} \cdot 3 \mathrm{H}_{2} \mathrm{O}$ prepared with a percentage molar ratio of $90 \%-10 \%$. The research was done using differential thermal analysis (TG, DTG, DTA), IR-spectrophotometry and WAXS. The above-mentioned substances changed the structure when heated for $1 \mathrm{~h}$ up to $500^{\circ} \mathrm{C}$ and $1000^{\circ} \mathrm{C} . \mathrm{MgHPO}_{4} \cdot 3 \mathrm{H}_{2} \mathrm{O}$ (Newberyite) changes its structure at $500^{\circ} \mathrm{C}$ into not completely formed $\mathrm{Mg}_{2} \mathrm{P}_{2} \mathrm{O}_{7}$ and at $1000^{\circ} \mathrm{C}$ into $\mathrm{Mg}_{2} \mathrm{P}_{2} \mathrm{O}_{7}$. Lithium carbonate $\left(20^{\circ}-1000^{\circ} \mathrm{C}\right)$ does not change its structure. Binary mixtures change the structure depending on the molar ratio and at $1000^{\circ} \mathrm{C}$ they form $\mathrm{Li}_{3} \mathrm{PO}_{4}, \mathrm{LiMgPO}_{4}, \mathrm{MgO}$ and $\mathrm{Mg}_{2} \mathrm{P}_{2} \mathrm{O}_{7}$. At the molar ratio of $90 \%$ $\mathrm{Li}_{2} \mathrm{CO}_{3}-10 \% \mathrm{MgHPO}_{4} \cdot 3 \mathrm{H}_{2} \mathrm{O}$ they form a sinter with the porcelain of the melting pot.
\end{abstract}

(Received 5 September, 2007; Accepted 17 December, 2007)

\section{INTRODUCTION}

In previous papers, results of investigation into the influence of temperature on substrates and binary mixtures containing $\mathrm{Li}_{3} \mathrm{PO}_{4}$ and $\mathrm{Mg}_{3}\left(\mathrm{PO}_{4}\right)_{2} \cdot 8 \mathrm{H}_{2} \mathrm{O}$ were presented ${ }^{1}$. Plenty of phase transformations and chemical reactions were observed, which encouraged us to carry out similar investigation using $\mathrm{Li}_{2} \mathrm{CO}_{3}$ instead of $\mathrm{Li}_{3} \mathrm{PO}_{4}$. Apart from citrate, bromide and acetate, lithium carbonate has diverse applications in pharmacology. ${ }^{2},{ }^{3}$ In Tobon ${ }^{4}$ research was carried out on thermal properties of lithium salts. The results made it possible to determine the thermal stability of lithium salts. In atmospheres containing oxygen each of the lithium organic salts is transformed into lithium carbonate. Together with other carbonates $\left(\mathrm{Na}^{+}, \mathrm{K}^{+}\right)$, lithium carbonate was used for testing sintering and mechanical properties of $\beta$-tricalcium phosphates $\left(\right.$ Yoshida $\left.^{5}\right)$. The authors of those papers also used $\mathrm{Li}_{2} \mathrm{CO}_{3}$ with silver ions to synthesize and test tricalcium phosphate as an antimicrobial agent ${ }^{6}$. The thermal reaction of $\mathrm{Li}_{2} \mathrm{CO}_{3}$ with $\mathrm{MgHPO}_{4} \cdot 3 \mathrm{H}_{2} \mathrm{O}$ in binary mixtures with percentage molar ratios from $90 \%$ to $10 \%$ is the subject of the present paper. Substrates and binary mixtures were tested at a temperature of $20^{\circ}, 500^{\circ}$ and $1000^{\circ} \mathrm{C}$. Thermal Differential Analysis, IR spectrophotometry and WAXS were methods of choice for carrying out the research.

\section{METHODOLOGY}

Chemicals-substrates: $\mathrm{Li}_{2} \mathrm{CO}_{3}(1)$, Aldrich cat:: 55413-2; $\mathrm{MgHPO}_{4} \cdot 3 \mathrm{H}_{2} \mathrm{O}(11)$, Aldrich cat.: 7782-75-4.

Preparation of the substrates and their binary mixtures: Substrates $(1,11)$ were used as supplied (TABLE 1). Each compound was grounded, sieved, and binary mixtures were prepared with percentage molar ratios of $90 \%$ to $10 \%$ as described by Umbreit ${ }^{7}$.

TABLE 1 Percentage molar ratios of substrates in binary mixtures.

\begin{tabular}{|c|c|c|c|c|c|c|c|c|c|c|c|}
\hline $\begin{array}{c}\text { Sample } \\
\text { number }\end{array}$ & 1 & 2 & 3 & 4 & 5 & 6 & 7 & 8 & 9 & 10 & 11 \\
\hline $\mathrm{Li}_{2} \mathrm{CO}_{3}$ & $\begin{array}{c}10 \\
0\end{array}$ & 9 & 8 & 7 & 6 & 5 & 4 & 3 & 2 & 10 & 0 \\
\hline $\mathrm{MgHPO}$ & 0 & 1 & 2 & 3 & 4 & 5 & 6 & 7 & 8 & 90 & 10 \\
$4 \cdot 3 \mathrm{H}_{2} 0$ & 0 & 0 & 0 & 0 & 0 & 0 & 0 & 0 & 0 & 90 \\
\hline
\end{tabular}

Preparation of sinters at $500^{\circ} \mathrm{C}$ and $1000^{\circ} \mathrm{C}$ : Substrates and binary mixtures were heated in melting pots at $500^{\circ} \mathrm{C}$ and $1000^{\circ} \mathrm{C}$ for $1 \mathrm{~h}$ as described by Umbreit ${ }^{7}$.

Apparatus and analytical procedure: Differential Thermal Analysis was performed using Derivatograph Q-1500D as reported by Umbreit?. IR analysis was carried out using tablets of potassium bromide and Carl Zeiss Jena spectrophotometer. WAXS radiography analysis was performed as described by Umbreit ${ }^{7}$. 


\section{RESULTS AND DISCUSSION}

Thermal analysis of $\mathrm{Li}_{2} \mathrm{CO}_{3}$ was carried out ranging from $20^{\circ}$ to $1000^{\circ} \mathrm{C}$ (FIGURE 1.1). This compound is characterized by the lack of mass change of the sample within the range from $20^{\circ}$ to $780^{\circ} \mathrm{C}$ (TG curve). There are no thermal transformations seen on the other curves (DTG and DTA). Above the temperature of $780^{\circ} \mathrm{C}$ phase transformation of lithium carbonate (DTA curve) with a maximum at $800^{\circ} \mathrm{C}$ and with a slight mass loss of the sample (TG curve) occurs. Thermal transformation of the other substrate, $\mathrm{MgHPO}_{4}$. $3 \mathrm{H}_{2} \mathrm{O}$, was presented in Umbreit ${ }^{8}$ and on FIGURE 1.2. The analysis of DTG and DTA curves of the binary mixtures shows that the addition of even $10 \%$ of $\mathrm{MgHPO}_{4} \cdot 3 \mathrm{H}_{2} \mathrm{O}$ to the binary system causes dehydration of the sample. In the second phase of the transformation a distinct transformation of $\mathrm{Li}_{2} \mathrm{CO}_{3}$ is evident as it takes place in the substrate itself (FIGURE 1.1). It was stated that, within the concentration of $\mathrm{MgHPO}_{4} \cdot 3 \mathrm{H}_{2} \mathrm{O}$ from $10 \%$ to $40 \%$ in the binary samples, the mass loss caused by the increase in temperature occurs due to the thermal transformation of $\mathrm{Li}_{2} \mathrm{CO}_{3}$ (TG curves) and proportional decrease of the endothermic maximum at $800^{\circ} \mathrm{C}$ on the DTA curve. After exceeding the ratio of $40 \% \mathrm{Li}_{2} \mathrm{CO}_{3}$ and $60 \% \mathrm{MgHPO}_{4} \cdot 3 \mathrm{H}_{2} \mathrm{O}$ (FIGURE 1.3), increasingly smaller mass loss of binary mixtures at $800^{\circ} \mathrm{C}$ on the TG curve and a gradually disappearing maximum on the DTA curve are observed. It follows from the above mentioned research that both substrates are involved in the phase transformation. The transformation which takes place at $800^{\circ} \mathrm{C}$ may be interesting from the point of view of physical chemistry; it has been proved in further studies carried out in this research.
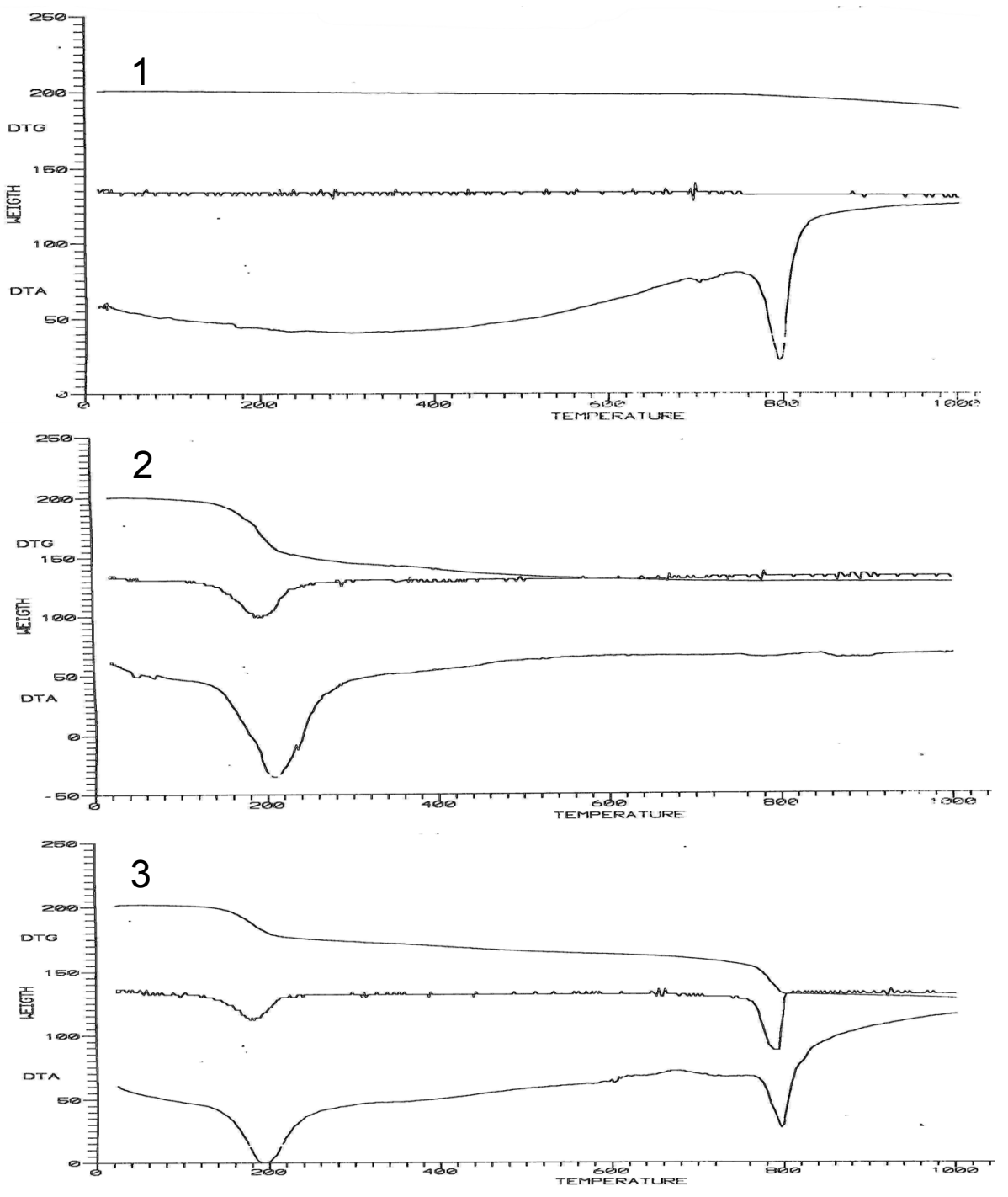

FIGURE 1 TG, DTG, DTA for $\mathrm{Li}_{2} \mathrm{CO}_{3}(1)$ and $\mathrm{MgHPO}_{4} \cdot 3 \mathrm{H}_{2} \mathrm{O}(2)$ and their binary mixture: $\mathrm{Li}_{2} \mathrm{CO}_{3}(50 \%)$ - $\mathrm{MgHPO}_{4} \cdot 3 \mathrm{H}_{2} \mathrm{O}(50 \%)$ (3). 
To this end, a series of tests were performed in which the substrates and their binary mixtures were heated for $1 \mathrm{~h}$ at $500^{\circ} \mathrm{C}$ and $1000^{\circ} \mathrm{C}$. Three series of tests were carried out in this way: non-heated; heated at $500^{\circ} \mathrm{C}$ and at $1000^{\circ} \mathrm{C}$ for $1 \mathrm{~h}$. They were subject to IR (FIGURE 2) and WAXS (FIGURE 3) analysis. Spectrophotometric IR analyses of non-heated $\mathrm{Li}_{2} \mathrm{CO}_{3}$ (FIGURE 2.1.1) show the characteristic bands of carbonates: - a wide band within the range of 1900 to $1100 \mathrm{~cm}^{-1}$ with a maximum at $1440 \mathrm{~cm}^{-1}$ which corresponds to the vibrations of $v_{3}\left(\mathrm{CO}_{3}{ }^{2-}\right)$,

- a narrow band within the range of 1100 to 1030 $\mathrm{cm}^{-1}$ with a maximum at $1081 \mathrm{~cm}^{-1}$ which corresponds to the $v_{1}$ vibrations of the carbonate group.

- a band within the range of 1030 to $809 \mathrm{~cm}^{-1}$ with a prominent maximum at $868 \mathrm{~cm}^{-1}$ which corresponds to the $v_{2}$ vibrations $\left(\mathrm{CO}_{3}{ }^{2-}\right)$,

- a small maximum at $728 \mathrm{~cm}^{-1}$ (FIGURE 2.1.1) was also observed.

The spectrum of $\mathrm{MgHPO}_{4} \cdot 3 \mathrm{H}_{2} \mathrm{O}$ (Figure 2.1.11) was discussed by Umbreit ${ }^{8}$. The analysis of spectra of binary mixtures reveals changes in absorbance frequencies in the range of $1900-810 \mathrm{~cm}^{-1}$.

The addition of $10 \%$ of $\mathrm{MgHPO}_{4} \cdot 3 \mathrm{H}_{2} \mathrm{O}$ (FIGURE 2.1.2) slightly changes the spectrum of $\mathrm{Li}_{2} \mathrm{CO}_{3}$. Starting from $20 \%$ molar ratio of lithium carbonate a change occurs in absorbance frequencies in the 1900$1100 \mathrm{~cm}^{-1}$ range; in this case, however, instead of one maximum two maxima were observed: they were increasingly more visible with the increase of the amount of $\mathrm{MgHPO}_{4} \cdot 3 \mathrm{H}_{2} \mathrm{O}$. Sample No. 4 has a small maximum at 1654 but sample No. 9 has an intense band with two maxima at $1640 \mathrm{~cm}^{-1}$ and $1700 \mathrm{~cm}^{-1}$.
The second change occurred in the range of 1603$1280 \mathrm{~cm}^{-1}$ of absorbance frequencies. Sample No. 4 has two small maxima and sample No. 9 has two distinct ones at $1470 \mathrm{~cm}^{-1}$ and $1426 \mathrm{~cm}^{-1}$. These changes disappear in the case of sample containing $10 \% \mathrm{Li}_{2} \mathrm{CO}_{3}$ and $90 \% \mathrm{MgHPO}_{4} \cdot 3 \mathrm{H}_{2} \mathrm{O}$ (Fig 2.1.10). The other maxima, in the frequency range from 1250 to $400 \mathrm{~cm}^{-1}$, are retained. They correspond to the bending - stretching vibrations due to the interactions between positive ions forming the individual compounds and their negative ions.

The analysis of the spectrum of $\mathrm{Li}_{2} \mathrm{CO}_{3}$ heated for $1 \mathrm{~h}$ at $500^{\circ} \mathrm{C}$ (FIGURE 2.2.1) shows the same absorption maxima as observed in the non-heated substrate. Slight differences occur only in slight changes in the maxima. For example: in the nonheated substrate, within the band of $1100-1080 \mathrm{~cm}^{-1}$ a maximum occurs at $1081 \mathrm{~cm}^{-1}$ and in the substrate heated for $1 \mathrm{~h}$ at $500^{\circ} \mathrm{C}$ it is observed at $1088 \mathrm{~cm}^{-1}$. Next tests in that series of research of binary mixtures which have increasingly greater contents of $\mathrm{MgHPO}_{4}$. $3 \mathrm{H}_{2} \mathrm{O}$ and heated for $1 \mathrm{~h}$ at $500^{\circ} \mathrm{C}$ reveal spectra characteristic of lithium carbonate within the wide band range of 1110 to $2250 \mathrm{~cm}^{-1}$ which has a maximum at $1530 \mathrm{~cm}^{-1}$.

In sample No. 2 this maximum occurs at $1162 \mathrm{~cm}^{-1}$ and in sample No. 5 at $1250 \mathrm{~cm}^{-1}$. With the increase of $\mathrm{MgHPO}_{4} \cdot 3 \mathrm{H}_{2} \mathrm{O}$ content from sample No. 3, two small maxima emerge in this broad band: one at $1485 \mathrm{~cm}^{-1}$ and the other at $1426 \mathrm{~cm}^{-1}$. These maxima are characteristic and they don't undergo any shift until the sample containing $80 \% \mathrm{MgHPO}_{4} \cdot 3 \mathrm{H}_{2} \mathrm{O}$ (FIGURE 2.2.9).

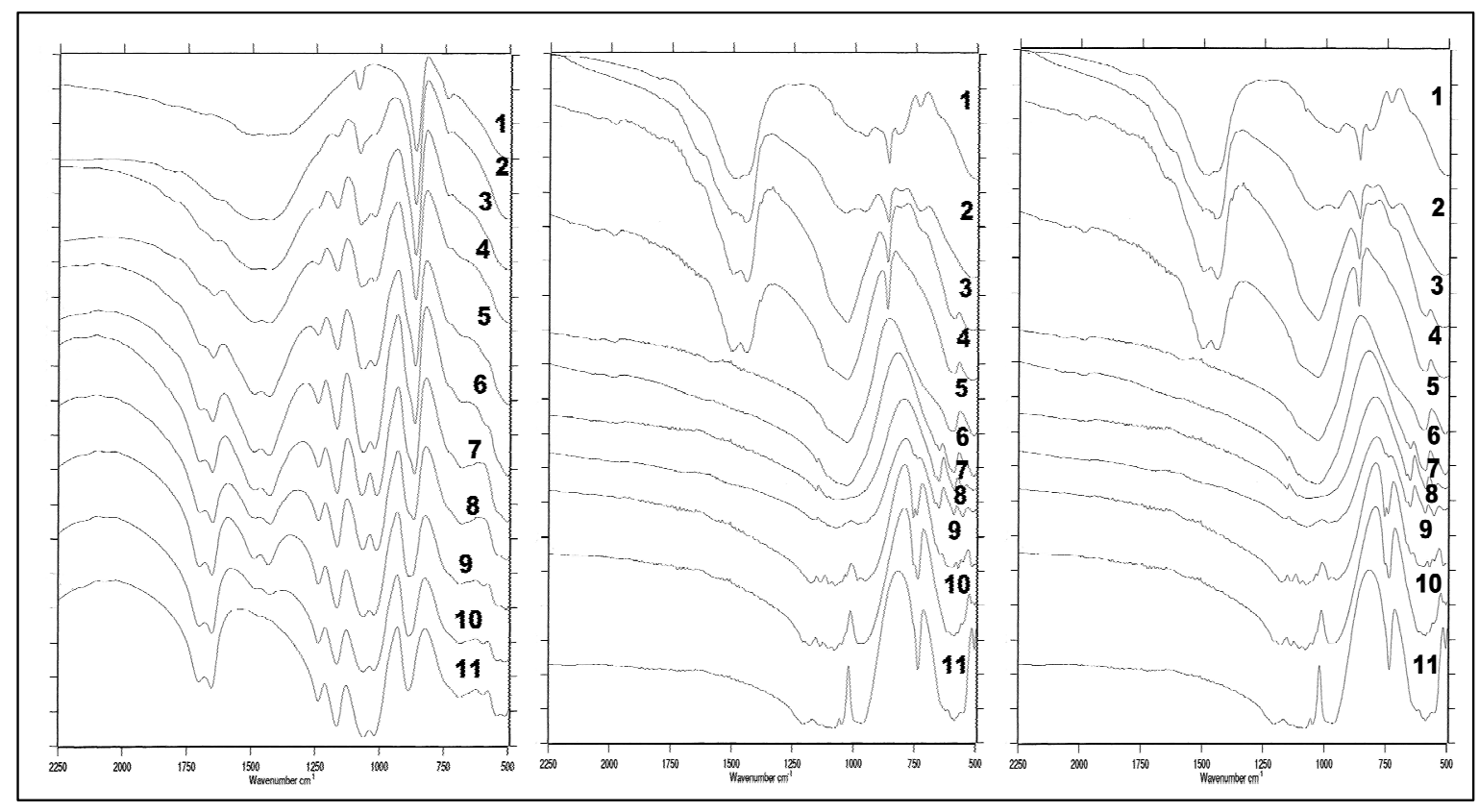

FIGURE 2 IR spectra of the samples non-heated (1), heated: $1 \mathrm{~h}$ at $500^{\circ} \mathrm{C}(2), 1 \mathrm{~h}$ at $1000^{\circ} \mathrm{C}(3)$ for $\mathrm{Li}_{2} \mathrm{CO}_{3}$ (sample 1), $\mathrm{MgHPO}_{4} \cdot 3 \mathrm{H}_{2} \mathrm{O}$ (sample 11) and their binary mixtures (samples 2-10). 


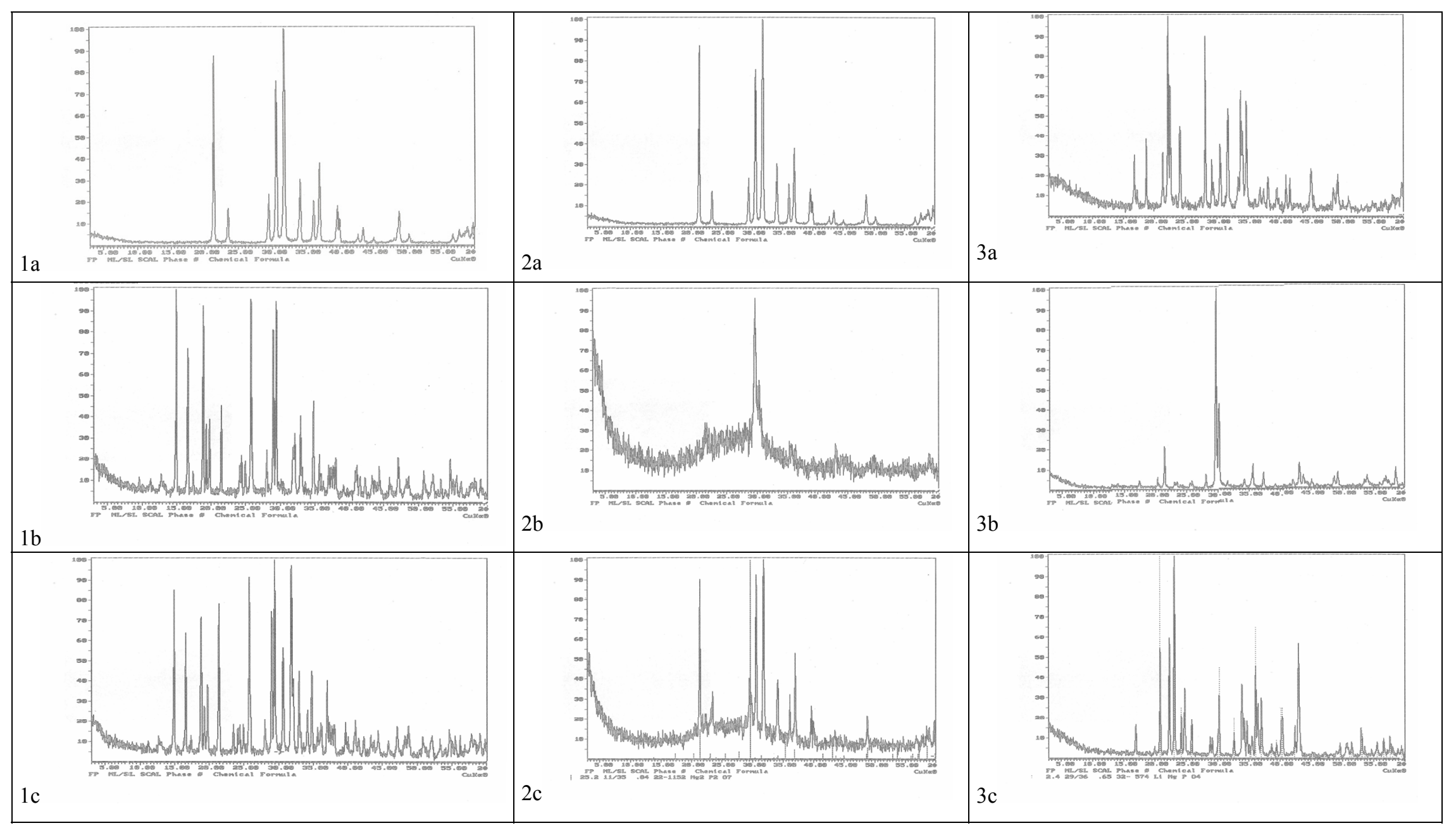

FIGURE 3 Diffractograms (WAXS) obtained for substrates $\mathrm{Li}_{2} \mathrm{CO}_{3}(\mathrm{a}) ; \mathrm{MgHPO}_{4} \cdot 3 \mathrm{H}_{2} \mathrm{O}(\mathrm{b})$ and their binary mixtures $(50 \%-50 \%)(\mathrm{c})$, non-heated (1) and heated for $1 \mathrm{~h}$ at $500^{\circ} \mathrm{C}(2)$ and for $1 \mathrm{~h}$ at $1000^{\circ} \mathrm{C} \mathrm{(3).}$ 
TABLE 2 Identification of substrates, $\mathrm{Li}_{2} \mathrm{CO}_{3}$ and $\mathrm{MgHPO}_{4} \cdot 3 \mathrm{H}_{2} \mathrm{O}$, and binary mixtures by powder X-ray diffractometry (WAXS).

\begin{tabular}{|c|c|c|c|c|}
\hline Temp. & Sample number & Chemical formula & Compound name & Identity card number \\
\hline \multirow{4}{*}{$20^{\circ} \mathrm{C}$} & $\begin{array}{c}1.1 \\
100 \%(1)\end{array}$ & $\mathrm{Li}_{2} \mathrm{CO}_{3}$ & Lithium carbonate & $22-1141$ \\
\hline & $\begin{array}{c}1.6: \\
50 \%(1)-50 \%(2)\end{array}$ & & Lithium carbonate & $22-1141$ \\
\hline & & $\mathrm{MgHPO}_{4} \cdot 3 \mathrm{H}_{2} \mathrm{O}$ & Newberyite & $35-780$ \\
\hline & $\begin{array}{c}1.11: \\
100 \%(2)\end{array}$ & $\mathrm{MgHPO}_{4} \cdot 3 \mathrm{H}_{2} \mathrm{O}$ & Newberyite & $\begin{array}{l}35-780 \\
20-153 \\
19-762 \\
\end{array}$ \\
\hline \multirow{4}{*}{$500^{\circ} \mathrm{C}$} & $\begin{array}{c}2.1: \\
100 \%(1) \\
\end{array}$ & $\mathrm{Li}_{2} \mathrm{CO}_{3}$ & Lithium carbonate & $22-1141$ \\
\hline & $\begin{array}{c}2.6: \\
50 \%(1)-50 \%(2)\end{array}$ & $\mathrm{Li}_{2} \mathrm{CO}_{3}$ & & $22-1141$ \\
\hline & & $\mathrm{Mg}_{2} \mathrm{P}_{2} \mathrm{O}_{7}$ & $\begin{array}{c}\text { Magnesium } \\
\text { pyrophosphate }\end{array}$ & $22-1152$ \\
\hline & $\begin{array}{c}2.11: \\
100 \%(2)\end{array}$ & $\mathrm{Mg}_{2} \mathrm{P}_{2} \mathrm{O}_{7}$ & $\begin{array}{c}\text { Magnesium } \\
\text { pyrophosphate }\end{array}$ & $22-1152$ \\
\hline \multirow{9}{*}{$1000^{\circ} \mathrm{C}$} & $\begin{array}{c}3.1: \\
100 \%(1) \\
\end{array}$ & $\begin{array}{l}\mathrm{Li}_{4} \mathrm{SiO}_{4} \\
\mathrm{Li}_{2} \mathrm{CO}_{3} \\
\end{array}$ & $\begin{array}{c}\text { Lithium Silicate } \\
\text { Lithium carbonate }\end{array}$ & $\begin{array}{c}20-637 \\
22-1141 \\
\end{array}$ \\
\hline & $\begin{array}{c}3.2: \\
90 \%(1)-10 \%(2)\end{array}$ & $\begin{array}{c}\mathrm{Li}_{4} \mathrm{SiO}_{4} * \\
\mathrm{Li}_{3,2} \mathrm{Mg}_{4} \mathrm{SiO}_{4} *\end{array}$ & $\begin{array}{c}\text { Lithium silicate } \\
\text { Lithium Magnesium } \\
\text { Silicate }\end{array}$ & $\begin{array}{l}20-637 \\
24-637\end{array}$ \\
\hline & $\begin{array}{c}3.3: \\
80 \%(1)-20 \%(2) \\
\end{array}$ & $\mathrm{Li}_{3} \mathrm{PO}_{4}$ & Lithium phosphate & $15-760$ \\
\hline & $\begin{array}{c}3.4: \\
70 \%(1)-30 \%(2)\end{array}$ & $\begin{array}{c}\mathrm{Li}_{3} \mathrm{PO}_{4} \\
\mathrm{Li}_{2} \mathrm{CO}_{3} \\
\mathrm{MgO}\end{array}$ & $\begin{array}{c}\text { Lithium phosphate } \\
\text { Lithium carbonate } \\
\text { Periclase, syn. }\end{array}$ & $\begin{array}{c}15-760 \\
22-1141 \\
4-829 \\
\end{array}$ \\
\hline & $\begin{array}{c}3.5: \\
50 \%(1)-50 \%(2)\end{array}$ & $\begin{array}{c}\mathrm{LiMgPO}_{4} \\
\mathrm{MgO} \\
\end{array}$ & $\begin{array}{c}\text { Lithium magnesium } \\
\text { phosphate } \\
\text { Periclase, syn. } \\
\end{array}$ & $\begin{array}{c}18-735 \\
32-574 \\
4-829 \\
\end{array}$ \\
\hline & $\begin{array}{c}3.8: \\
30 \%(1)-70 \%(2)\end{array}$ & $\mathrm{LiMgPO}_{4}$ & $\begin{array}{l}\text { Lithium magnesium } \\
\text { phosphate }\end{array}$ & $32-574$ \\
\hline & $\begin{array}{c}3.9: \\
20 \%(1)-80 \%(2)\end{array}$ & $\mathrm{LiMgPO}_{4}$ & $\begin{array}{c}\text { Lithium magnesium } \\
\text { phosphate }\end{array}$ & $32-574$ \\
\hline & $\begin{array}{c}3.10: \\
10 \%(1)-90 \%(2)\end{array}$ & $\begin{array}{l}\mathrm{LiMgPO}_{4} \\
\mathrm{Mg}_{2} \mathrm{P}_{2} \mathrm{O}_{7}\end{array}$ & $\begin{array}{c}\text { Lithium magnesium } \\
\text { phosphate } \\
\text { Magnesium } \\
\text { pyrophosphate } \\
\end{array}$ & $\begin{array}{c}32-574 \\
8-38\end{array}$ \\
\hline & $\begin{array}{c}3.11: \\
100 \%(2)\end{array}$ & $\mathrm{Mg}_{2} \mathrm{P}_{2} \mathrm{O}_{7}$ & $\begin{array}{l}\text { Magnesium } \\
\text { pyrophosphate }\end{array}$ & $\begin{array}{c}8-38 \\
32-626\end{array}$ \\
\hline
\end{tabular}

* $\mathrm{Li}_{4} \mathrm{SiO}_{4}$ and $\mathrm{Li}_{3,2} \mathrm{Mg}_{4} \mathrm{SiO}_{4}$ were obtained in a sintering reaction of the melting pot with $\mathrm{Li}_{2} \mathrm{CO}_{3}$ in the presence of $\mathrm{MgHPO}_{4} \cdot 3 \mathrm{H}_{2} \mathrm{O}$ 
The shift takes place in the absorption minimum which limits the carbonate spectrum toward longer waves, namely $1110 \mathrm{~cm}^{-1}, 1162 \mathrm{~cm}^{-1}, 1250 \mathrm{~cm}^{-1}$ and $1353 \mathrm{~cm}^{-1}$ for samples No. 1, No. 2, No. 5 and No. 9 , respectively. In all the binary mixtures magnesium pyrophosphate tetrabasic forms. This is proven by maxima in two ranges, namely one band within the range of 1162-912 $\mathrm{cm}^{-1}$ with two maxima at $1088 \mathrm{~cm}^{-1}$ and $1030 \mathrm{~cm}^{-1}$ and the other band within the range of $912-816 \mathrm{~cm}^{-1}$ with a maximum at $860 \mathrm{~cm}^{-1}$. In this spectral range an increase or decrease of the characteristic maxima occurs only in the same ranges until the sample labeled as No. $10\left(10 \% \mathrm{Li}_{2} \mathrm{CO}_{3}\right.$ and $\left.90 \% \mathrm{MgHPO}_{4} \cdot 3 \mathrm{H}_{2} \mathrm{O}\right)$. The spectrum of sample No. 11 shows a structure of magnesium pyrophosphate tetrabasic not completely formed when $\mathrm{MgHPO}_{4}$. $3 \mathrm{H}_{2} \mathrm{O}$ is heated for $1 \mathrm{~h}$ at $500^{\circ} \mathrm{C}$.

The heating of the samples of substrates and their binary mixtures for $1 \mathrm{~h}$ at $1000^{\circ} \mathrm{C}$ caused significant changes in their structures, which was reflected in their IR spectra (FIGURE 2.3, spectra 1-11). The spectrum of $\mathrm{Li}_{2} \mathrm{CO}_{3}$ shows two large absorption maxima, one within the range of $1780-1280 \mathrm{~cm}^{-1}$ with a maximum at $1470 \mathrm{~cm}^{-1}$. These maxima occur also in the next samples (No. 2-4). With the decrease of $\mathrm{Li}_{2} \mathrm{CO}_{3}$ from $90 \%$ to $70 \%$ and increase of $\mathrm{MgHPO}_{4} \cdot 3 \mathrm{H}_{2} \mathrm{O}$, this band divides into two small maxima at $1500 \mathrm{~cm}^{-1}$ and $1449 \mathrm{~cm}^{-1}$. With a larger content of $\mathrm{MgHPO}_{4} \cdot 3 \mathrm{H}_{2} \mathrm{O}$ (from sample No. 5) the band fades. The second band in IR for $\mathrm{Li}_{2} \mathrm{CO}_{3}$ extends from $1280 \mathrm{~cm}^{-1}$ to $750 \mathrm{~cm}^{-1}$ and divides into three absorption maxima at $963 \mathrm{~cm}^{-1}$, $860 \mathrm{~cm}^{-1}$ and $809 \mathrm{~cm}^{-1}$. The maximum at $963 \mathrm{~cm}^{-1}$ extends and slightly shifts toward shorter waves. The maximum at $860 \mathrm{~cm}^{-1}$ is retained and does not change its position in the samples containing 90, 80 and $70 \%$ of $\mathrm{Li}_{2} \mathrm{CO}_{3}$. However, the maximum at $809 \mathrm{~cm}^{-1}$ fades with the decrease of $\mathrm{Li}_{2} \mathrm{CO}_{3}$ and does not exist in sample No 5. From sample No. 3 and 4 which contain $80 \%$ and $70 \% \mathrm{Li}_{2} \mathrm{CO}_{3}$ one large band is observed within the range of $1500-810 \mathrm{~cm}^{-1}$ with a maximum at $1030 \mathrm{~cm}^{-1}$. This maximum is very characteristic of $\mathrm{PO}_{4}{ }^{3-}$. The spectra of samples 5-8 containing $60 \%-$ $30 \% \mathrm{Li}_{2} \mathrm{CO}_{3}$ are very similar and characteristic of $\mathrm{LiMgPO}_{4}$. With the increase of $\mathrm{MgHPO}_{4} \cdot 3 \mathrm{H}_{2} \mathrm{O}$ content, the spectra become increasingly more characteristic of the pyrophosphate spectrum. The structure of pyrophosphate is observed in sample No. 11.

To substantiate the structure of individual substrates prepared from the binary mixtures and also compounds formed during the heating of the samples at $500^{\circ} \mathrm{C}$ and $1000{ }^{\circ} \mathrm{C}$ roentgenographic analyses were carried out using a powder WAXS diffractometer. The results obtained were characterized with bibliographical identification cards contained in the library of the XRAYAN system. The results are reported in FIGURE 3 and TABLE 2. The diagrams in FIGURE 3 "a" presents X-ray patterns for non-heated $\mathrm{Li}_{2} \mathrm{CO}_{3}$ (1a), heated for one hour at $500{ }^{\circ} \mathrm{C}(2 \mathrm{a})$ and heated for one hour at $1000{ }^{\circ} \mathrm{C}(3 \mathrm{a})$. The examination of non-heated sample evidenced that pure $\mathrm{Li}_{2} \mathrm{CO}_{3}$ is present. The vertical lines came from the base of $\mathrm{X}$ RAYAN programme confirm the presence of this compound (ID: 22-1141). The annealing in $500{ }^{\circ} \mathrm{C}$ doesn't change the structure of the investigated samples. The X-ray pattern for the samples annealed for one hour at $1000^{\circ} \mathrm{C}$ demonstrated changes. Apart $\mathrm{Li}_{2} \mathrm{CO}_{3}$ there is present in majority $\mathrm{Li}_{4} \mathrm{SiO}_{4}$ (ID: $20-$ 637). In similar way the identification analysis of another systems was performed (FIGURE $3 \mathrm{~b}, \mathrm{c}$ ). The results of all observed structural changes are presented in the TABLE 2.

\section{REFERENCES}

1. M.H.Umbreit, A. Jedrasiewicz, J. Klos, M. Zabicka, J. Inorg. Phosph. Chem.- Phosphorus Research Bulletin (Japan), 18, 15 (2005)

2. M. Zajac, E. Pawelczyk, Pharmaceutical Chemistry (Chemia Lekow), AM Poznan (2000).

3. M. Boresewicz, Farmakoterapia w psychiatrii $i$ neurologii, 1,40 (2000).

4. G.E. Tobon- Zapata, E.G. Ferrer, S.B. Etcheverry, E.J. Baran, J. Therm. Anal., 61,29(2000).

5. K. Yoshida, M. Mitamura, K. Hashimoto, Y. Toda, T. Kanazawa, S. Udagawa, J.Inorg. Phosph. Chem. - Phosphorus Research Bulletin (Japan), 13, 271 (2002)

6. K. Hashimoto, K. Yoshida, Y. Toda, T. Kanazawa, S. Udagawa, J. Inorg. Phosph. Chem.Phosphorus Research Bulletin (Japan), 13, 123 (2002).

7. M.H.Umbreit, A. Jedrasiewicz, M. Boudraa, J. Inorg. Phosph. Chem. - Bulletin Research Bulletin (Japan), 13, 243 (2002).

8. M.H.Umbreit, A. Jedrasiewicz, J. Klos, A. Walowska, J. Inorg. Phosph. Chem. - Bulletin Research Bulletin (Japan), 14, 57 (2002). 